\title{
Presence and characterization of Escherichia coli virulence genes isolated from diseased pigs in the central region of Argentina
}

\author{
Fernando A. Bessone, Gabriela Bessone, Sebastián Marini, María B. Conde, Fabrisio E. Alustiza and Gustavo Zielinski \\ Animal Health Group, INTA - Estación Experimental Agropecuaria Marcos Juárez, Postal Code 2580, Córdoba, Argentina. \\ Corresponding author: Fernando A. Bessone, e-mail: bessone.fernando@inta.gob.ar \\ Co-authors: GB: bessonegabriela@gmail.com, SM: marini.sebastian@inta.gob.ar, MBC: conde.maria@inta.gob.ar, \\ FEA: alustiza.fabrisio@inta.gob.ar, GZ: zielinski.gustavo@inta.gob.ar \\ Received: 03-04-2017, Accepted: 13-07-2017, Published online: 18-08-2017
}

doi: 10.14202/vetworld.2017.939-945 How to cite this article: Bessone FA, Bessone G, Marini S, Conde MB, Alustiza FE, Zielinski G (2017) Presence and characterization of Escherichia coli virulence genes isolated from diseased pigs in the central region of Argentina, Veterinary World, 10(8): 939-945.

\begin{abstract}
Background: The main pathogen of neonatal and post weaning diarrhea and edema disease (ED) is Escherichia coli and pathotypes involved are enterotoxigenic, enteropathogenic, and shiga toxigenic (ETEC, EPEC, and STEC, respectively). Those diseases cause economic loss in pig production.
\end{abstract}

Aim: The aim of this work was to evaluate the presence of strains expressing virulence markers genes and the antibiotic susceptibility profiles of $E$. coli from clinical cases of post weaning diarrhea and ED in farms in the central area of Argentina.

Materials and Methods: Intensive pig farms from the central region of Argentina were sampled. Intestinal mucosa swabs from pigs with diarrhea were taken, seeded on MacConkey agar plates, biochemically typified and tested by polymerase chain reaction (PCR). Antibiograms were made by disk-diffusion method.

Results: A total of 54 strains from clinical cases studied showed PCR findings: $88.88 \%$ (48/54) expressed at least one gene coding for a virulence factor. Colonization factors found were: $39.58 \%$ of strains had $F 18,33.33 \%$ were $F 4$ and $31.25 \%$ adhesin involved in diffuse adherence-I; $29.17 \%, 25 \%$, and $2.1 \%$ expressed $L T, S T b$, and $S T a$, respectively. $25 \%$ were $S T x$ and $16.67 \%$ were eae positive. Only $2.1 \%$ were $S T x 2$. The most active antibiotics against most strains were gentamicin and ceftiofur, but resistance profiles against many antibiotics were found.

Conclusion: High circulation of pathogens strains of $E$. coli among pigs with diarrhea with an extended antibiotic resistance profile.

Keywords: antibiotic resistance profile, Escherichia coli, pig, virulence genes.

\section{Introduction}

Porcine diarrhea is a disease that causes death and economic loss in swine production [1-5]. Enterotoxigenic, enteropathogenic, and shiga toxigenic (ETEC, EPEC, and STEC, respectively) pathotypes of Escherichia coli are the major pathogens responsible for neonatal diarrhea, post weaning diarrhea and edema disease (ED) in pigs [1], affecting almost all stages of production [2-4].

ETEC enterocyte adhesion is mediated by fimbriae (F) such as F4 (K88), F5 (K99), F6 (P987), F18, and F41 and is capable of producing enterotoxins which act on enterocytes. According to their thermal stability, enterotoxins are classified as heat-stable (STa, STb, and EAST1) and heat-labile (LTI and LTII) [5]. STEC strains produce shiga toxin (STx 1 and $S T \times 2$ ) and an adhesion protein called intimin (encoded by the eae gene) which is responsible for microvilli attaching and effacing on enterocytes surface [6], this

\footnotetext{
Copyright: Bessone, et al. Open Access. This article is distributed under the terms of the Creative Commons Attribution 4.0 International License (http://creativecommons.org/licenses/ by/4.0/), which permits unrestricted use, distribution, and reproduction in any medium, provided you give appropriate credit to the original author(s) and the source, provide a link to the Creative Commons license, and indicate if changes were made. The Creative Commons Public Domain Dedication waiver (http:// creativecommons.org/publicdomain/zero/1.0/) applies to the data made available in this article, unless otherwise stated.
}

protein is also important in EPEC pathotype. Some strains expressing F18 and the adhesin involved in diffuse adherence (AIDA) are associated to ED and produce STx2e toxin $[2,7,8]$. Other strains compatible with EPEC produce intimin without expression of any other associated toxins but are capable of inducing a typical lesion of attaching and effacing microvilli on enterocytes surface [9].

Certain STEC strains, particularly enterohemorrhagic $E$. coli, may infect pigs; causing bloody diarrhea, hemorrhagic colitis, and/or hemolytic uremic syndrome in humans, which grants zoonotic importance to these strains [2]. The most important toxins produced by STEC are STx2e, EAST1, $\alpha$-hemolysin, STx1, and/or STx2 [10].

Intensification of the porcine industry has led producers to carry out widespread feeding practices such as incorporation of antibiotics to feed, as a disease therapeutic strategy or as growth promoters [11]. Many antibiotics used for pig production are also important in human medicine. Dissemination of antibiotic resistance to humans might ensue from these practices $[12,13]$. Therefore, it is very important to know which the antibiotics resistance profiles are prevailing in the farm's $E$. coli strains, to prevent usage of those antibiotics which are also used in human medicine but are still active against the pathogen. 
Authors from different countries reported the prevalence of $E$. coli pathotypes for different categories of pigs [14-18]. However, not enough information about confirmatory diagnosis of virulent strains of $E$. coli from clinical cases is available in Argentina. Knowledge of E. coli pathotypes infecting the farms plus antibiotic susceptibility profiles is very important tools for pig producers to build solid therapeutic and preventive strategies.

The central aim of this work was to evaluate the presence of strains expressing virulence markers genes and the antibiotic susceptibility profiles of E. coli from clinical cases of post weaning diarrhea and ED occurred in farms in the central area of Argentina.

\section{Materials and Methods}

\section{Ethical approval}

In order to guarantee a safe, correct and carefully handling of pigs, authors proceeded according to specifications of international Ethic Guidelines (Internal Ethical Committee CICUAE Res. 533/16). However, the procedures performed do not cause discomfort to animals.

\section{Farms}

Intensive pig production farms in the central region of Argentina (states of Córdoba, Santa Fe, Buenos Aires, Entre Ríos and San Luis, the country's most important production area) were sampled according to the clinical cases emergency. All farms included in this study had the following characteristics: High health status, 200500 sows, automatized feed systems, parturition control, reduced waste contact, controlled environmental temperature, and permanent veterinarian assistance.

\section{Bacterial isolates processing}

Intestinal mucosa swabs samples were collected from clinical cases of piglets with post weaning diarrhea and/or with ED. Samples were inoculated on MacConkey agar plates (Britannia) and $5 \%$ equine blood agar plates (Britannia) to check $\beta$-hemolysis. After $24 \mathrm{~h}$ at $37^{\circ} \mathrm{C} \mathrm{Gram}$-staining was performed on organisms of emerging colonies to corroborate bacterial morphology. For biochemical characterization [15] hydrogen SulfideIndole-Motility (SIM) (Oxoid), Methyl Red-Voges Proskauer (MR-VP) (Britannia), citrate (Britannia), amino acids decarboxylation (arginine, lysine, and ornithine) (Britannia), oxidase (Britannia), catalase, three sugar iron (Oxoid) tests were carried out. All $E$. coli isolates were lyophilized until molecular characterization was made.

\section{Molecular characterization}

A total of $54 \mathrm{E}$. coli isolates were tested by polymerase chain reaction (PCR). DNA was obtained using a commercial kit (Fermentas) according to manufacturer instructions for Gram-negative bacteria. These extracts were used as reaction templates. Fimbriae and toxins genes primers studied were: $S T a, S T b, L T, F 4$, F18, VT1 (STX1), VT2 (STx2), eae, EAST1, AIDA-I, and $R f b(\mathrm{O} 157)$ [1,15], sequences are listed in Table-1. The PCR mixture was composed by $50 \mathrm{ng}$ of template, $50 \mu \mathrm{M}$ of each primer (Fagos), $100 \mu \mathrm{M}$ deoxynucleotide triphosphates (Promega), $1.5 \mu \mathrm{M}$ of $\mathrm{MgCl}_{2}$, $1 \times$ buffer (5X-Go Taq Promega), and 0.5 U of Taq Polymerase (Promega) with a final volume of $25 \mu \mathrm{L}$. Reactions were subjected to one initial denaturalization cycle of $94^{\circ} \mathrm{C}$, followed by 30 cycles of $30 \mathrm{~s}$ at $94^{\circ} \mathrm{C}$ (denaturalization), $30 \mathrm{~s}$ at $58^{\circ} \mathrm{C}$ (primers annealing), $30 \mathrm{~s}$ at $72^{\circ} \mathrm{C}$ (extension); finally $2 \mathrm{~min}$ at $72^{\circ} \mathrm{C}$ (final extension). Reference strains of E. coli were used as pathotype and positive control reaction [1] (Table-1).

Table-1: Virulence factor genes, primer sequences.

\begin{tabular}{|c|c|c|c|}
\hline Virulence factor & Sequence $\left(5^{\prime}-3^{\prime}\right)-$ sense/antisense & Amplicon size (bp) & $\mathrm{T}^{\circ}$ annealing $\left({ }^{\circ} \mathrm{C}\right)$ \\
\hline STa & $\begin{array}{l}\text { TCC CCT CTT TTA GTC AGT CAA CTG } \\
\text { GCA CAG GCA GGA TTA CAA CAA AGT }\end{array}$ & 163 & $60^{\circ}$ \\
\hline$S T b$ & $\begin{array}{l}\text { GCA ATA AGG TTG AGG TGA T } \\
\text { GCC TGC AGT GAG AAA TGG AC }\end{array}$ & 368 & $60^{\circ}$ \\
\hline$L T$ & $\begin{array}{l}\text { TTA CGG CGT TAC TAT CCT CTC TA } \\
\text { GGT CTC GGT CAG ATA TGT GAT TC }\end{array}$ & 275 & $60^{\circ}$ \\
\hline$F 4(K 88)$ & $\begin{array}{l}\text { ATC GGT GGT AGT ATC ACT GC } \\
\text { AAC CTG CGA CGT CAA CAA GA }\end{array}$ & 601 & $60^{\circ}$ \\
\hline$F 18$ & $\begin{array}{l}\text { GTG AAA AGA CTA GTG TTा ATT TC } \\
\text { CTT GTA AGT AAC CGC GTA AGC }\end{array}$ & 510 & $60^{\circ}$ \\
\hline$V T 1(S T \times 1)$ & $\begin{array}{l}\text { TTA GAC TTC TCG ACT GCA AAG } \\
\text { TGT TGT ACG AAA TCC CCT CTG }\end{array}$ & 530 & $60^{\circ}$ \\
\hline$V T 2(S T \times 2)$ & $\begin{array}{l}\text { CTA TAT CTG CGC CGG GTC TG } \\
\text { AGA CGA AGA TGG TCA AAA CG }\end{array}$ & 327 & $60^{\circ}$ \\
\hline eae & $\begin{array}{l}\text { CAT TAT GGA ACG GCA GAG GT } \\
\text { ATC TTC TGC GTA CTG CGT TCA }\end{array}$ & 790 & $60^{\circ}$ \\
\hline EAST I & $\begin{array}{l}\text { TCG GAT GCC ATC AAC ACA GT } \\
\text { GTC GCG AGT GAC GGC TIT GTA G }\end{array}$ & 125 & $55^{\circ}$ \\
\hline$A I D A-I$ & $\begin{array}{l}\text { for } 5 \times \text { ACA GTA TCA TAT GGA GCC A } \\
\text { rev } 5 \times \text { TGT GCG CCA GAA CTA TTA }\end{array}$ & 585 & $55^{\circ}$ \\
\hline Rfb 0157 & $\begin{array}{l}\text { CGG ACA TCC ATG TGA TAT GG } \\
\text { TTG CTA TGT ACA GCT AAT CC }\end{array}$ & 259 & $55^{\circ}$ \\
\hline
\end{tabular}

$A I D A=$ Adhesin involved in diffuse adherence 
A standard electrophoresis in $2 \%$ of agarose in tris-acetate EDTA buffer stained with ethidium bromide performed at $100 \mathrm{~V}$ during $30 \mathrm{~min}$ was used to reveal the amplified products. Visualization of amplicons was made under transilluminator (UV $-\lambda$ $300 \mathrm{~nm}$ ), and a $100 \mathrm{pb}$ ladder was used. Gels were photographed with a Kodak Easy Share Z7590 camera system and evaluated with Kodak Digital Science 1D software [1].

\section{Antimicrobial profiles}

A disk-diffusion method was performed according to recommendations of the National Committee for Clinical Laboratory Standards [19]. Briefly, 12 different antibiotics were assayed: Tiamuline (TIM), enrofloxacin, ceftiofur (CTF), ampicillin, tilmicosin, erythromycin, lincomycin, espectinomicina, florfenicol, gentamicin (GEN), trimethoprim sulfamethoxazole, and tylosin. The manufacturer guidelines were used for inhibition halo interpretation. Multiple antibiotic resistances were defined as isolates showing three or more antimicrobial classes resistance [20].

\section{Statistical analysis}

To evaluate associations between variables (genes, clinical signs, states, and season) contingency tables were used, through exact Fisher's test. When statistical association was revealed, multivariate test "multiple correspondence analysis" was applied to know levels of variable relation. SAS version 9.2 software and InfoStat version 2015 [21] were employed.

Table-2: Frequencies of general pathotypes distribution.

\begin{tabular}{lccl}
\hline $\begin{array}{l}\text { Virulence } \\
\text { gene }\end{array}$ & Proportion & Frequency $(\%) *$ & $\begin{array}{l}\text { Pathotype } \\
\text { associated }\end{array}$ \\
\hline F18 & $19 / 48$ & 39.58 & \\
F4 & $16 / 48$ & 33.33 & \\
AIDA-I & $15 / 48$ & 31.25 & ETEC \\
LT & $14 / 48$ & 29.17 & \\
STb & $12 / 48$ & 25 & \\
STa & $8 / 48$ & 16.67 & \\
STx & $12 / 48$ & 25 & STEC \\
ST $\times 2$ & $1 / 48$ & 2.1 & \\
eae & $8 / 48$ & 16.67 & EPEC \\
\hline
\end{tabular}

*These values are not additives, some associations between genes were found. AIDA=Adhesin involved in diffuse adherence, ETEC=Enterotoxigenic

Escherichia coli, STEC=Shigatoxigenic Escherichia coli, $\mathrm{EPEC}=$ Enteropathogenic Escherichia coli

\section{Results}

Bacterial isolates and molecular characterization

All isolates were biochemically compatible with E. coli (SIM- -/+/+; MRVP- +/-; citrate -; arginine - , lysine + ; ornithine + ; oxidase - ; catalase + ; TSI $+/+$ ). Of 54 strains from clinical cases studied, $88.88 \%$ $(48 / 54)$ expressed at least one gene coding for virulence factor. PCR results showed that $87.5 \%(42 / 48)$ of strains expressed EAST1, a heat-stable toxin usually associated to enteroaggregative $E$. coli, but also associated with ETEC strains and diffuse adherence $E$. coli. Results of these findings are summarized in Table-2.

The most frequent combinations of virulence factors shown in Table-3. Severity of diarrhea and ED was related to F4/EAST1 (16.7\%) and STb/LT/ F18/Stx1/East1/AIDA-I (8.3\%) combinations. On the other hand, STb/LT/F4/EAST1 (6.3\%) was observed in strains obtained from post weaning diarrhea cases and ED. The other virulence factor combinations observed were associated with less severe disease causes.

\section{Antimicrobial profiles}

Table-4 summarizes the results of antibiograms. According to these findings, the most suitable antibiotics for a therapeutic approach were GEN and CTF.

The correspondence between isolates and antibiotics resistance was shown in Figure-1 (Table-5). Six groups of strains were observed $(50 \%$ of distance), three of each included one strain distanced from the other three groups. Among these groups, one of each included two principal clusters with 23 strains; the other group was formed by two clusters with two strains each and finally one group with one strain.

\section{Discussion}

This work revealed the frequency of pathotypes of $E$. coli isolated from post weaning diarrhea and ED cases in swine from the central region of Argentina, and their relation to antimicrobial susceptibility. We found combinations of virulence factors strongly associated with severity of disease [1-3,14]: F4/ EAST1 (16.7\% of strains), STb/LT/F18/Stxl/East1/ AIDA-I (8.3\%), and STb/LT/F4/EAST1 (6.3\%); similar findings were reported by Moredo et al. $[1,14]$. However, strains expressing only one virulence factor were also found on diseased pigs, therefore those

Table-3: Virulence factors combination.

\begin{tabular}{lccc}
\hline Genotypes combinations & Frequency (\%) & Diarrhea (\%) & ED (\%) \\
\hline F4/East1 & $8(16.7)$ & $4(8.3)$ & $4(8.3)$ \\
STb/LT/F18/St $\times 1 /$ East1/AIDA-I & $4(8.3)$ & $4(8.3)$ & - \\
STb/LT/F4/East1 & $3(6.3)$ & $2(4.2)$ & $1(2.1)$ \\
STb/LT/F18/Eae/East1/AIDA-I & $2(4.2)$ & $2(4.2)$ & - \\
F4/Eae/East1 & $1(2.1)$ & - & $1(2.1)$ \\
STa/F18/St $1 /$ St 2/East1/AIDA-I & $1(2.1)$ & $12(27.1)$ & - \\
Total & $19(39.7)$ & $6(12.5)$ \\
\hline
\end{tabular}

Data represent: $\mathrm{n}(\%)$. AIDA=Adhesin involved in diffuse adherence, ED=Edema disease 
virulence factors could also be regarded as important virulence markers (e.g., EAST1, STa, F4, F18, Stxl, Stx2, and eae). Limited information about E. coli pathotypes is available in our country and it is not updated $[1,14,15,22]$.

The results presented do not agree with those informed by Parma et al. [22], who reported not having found characteristic virulence genes of ETEC and STEC strains among their isolates. However, Moredo et al. [14] showed similar findings to ours, but in pigs without clinical signs. Genes reported by

Table-4: Antibiotic profile, findings frequency.

\begin{tabular}{lccc}
\hline Antibiotic & $\begin{array}{c}\text { Sensitive } \\
(\mathbf{\%})\end{array}$ & $\begin{array}{c}\text { Intermediate } \\
(\mathbf{\%})\end{array}$ & $\begin{array}{c}\text { Resistant } \\
(\mathbf{\%})\end{array}$ \\
\hline ENR & 33.33 & 9.53 & 57.14 \\
CEF & 66.66 & 9.54 & 23.80 \\
AMP & 19.05 & 19.05 & 61.90 \\
TIM & 9.52 & 19.05 & 71.43 \\
TIL & 4.76 & 19.05 & 76.19 \\
ERY & 4.76 & 19.05 & 76.19 \\
LIN & 4.76 & 19.05 & 76.19 \\
SPC & 14.29 & 23.81 & 61.90 \\
FFN & 38.10 & 14.28 & 47.62 \\
GEN & 85.71 & 4.77 & 9.52 \\
TMS & 31.03 & 27.60 & 41.37 \\
TYL & 3.45 & 0 & 96.55 \\
\hline
\end{tabular}

ENR=Enrofloxacin, $C E F=$ Ceftiofur, $\mathrm{AMP}=$ Ampicillin, TIM=Tiamuline, $\mathrm{TIL}=$ Tilmicosin, ERY=Erythromycin, $\mathrm{LIN}=$ Lincomycin, SPC=Spectinomycin, FFN=Florfenicol, GEN=Gentamicin, TMS=Trimethoprim sulfamethoxazole, TYL=Tylosin
Moredo et al. were $S T x 1$ (STEC) and EAST1 (ETEC), they did not find $R f b$ O157, which was found in our work. Related to colonization factors and toxins F18 (40.4\%), F4 (4.2\%), STb (25\%), and STa (2.1\%), respectively, Moredo et al. [1] reported frequencies similar to ours, but we found differences regarding $L T$, which we found more frequently. These genes coding for important virulence factors have high pathogenic potential and may trigger piglet diarrhea, under adequate conditions. Therefore, the absence of disease reported by Moredo et al. might be related to the application of adequate environmental, hygienic, and sanitary measures [23]. Another difference was in gene coding for intimine (eae), not found by Moredo et al. [14], but detected (16.67\%) in this work. In agreement with Choi et al. [24] EAST1 was the most frequent virulence factor found both individually or in association with F4. STb and $L T$ were genes found without any association by Choi et al. [24], but contrarily to that report, in our work $S T b$ and $L T$ were found related to EAST1. A high proportion of EAST1STa in pigs with diarrhea was detected [25], but we only found one strain with this association (Table-2). We found F4 and F18 in both diseases and LT in post weaning disease (PD) and one case of edema disease (ED).

The shiga toxins (STx1, STx2 and its variants), intimine protein and the enterohemolysin are major virulence factors of STEC [26]. Although no O157 gene was found, we obtained a prevalence of $25 \%$

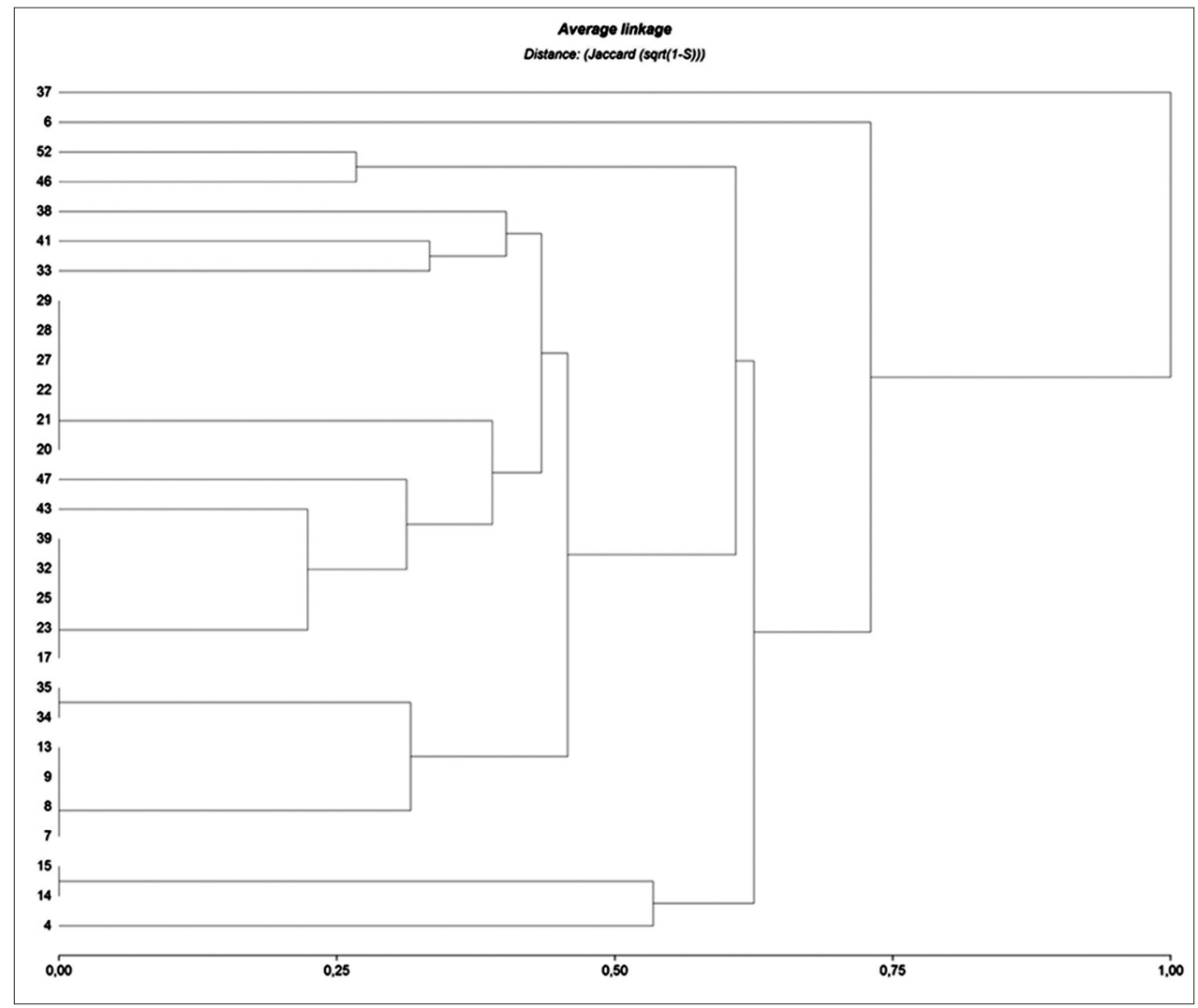

Figure-1: Multivariate analysis of antibiotic resistance. Dendrogram showed clusters of strains associated according to each resistance profile. Table-4 related numbers with strain. 
Table-5: Association between genotype and antibiotic profile, explanation of Figure-1.

\begin{tabular}{|c|c|c|c|c|}
\hline \multirow{2}{*}{$\begin{array}{l}\text { Sample } \\
\text { ID }\end{array}$} & \multirow[t]{2}{*}{ Genotype } & \multicolumn{3}{|l|}{ Antibiotic profile } \\
\hline & & Sensibility & Intermediate & Resistance \\
\hline 4 & STb-LT-F18-eae-EASTI-AIDA-I & CEF, AMP, FFN, GEN, TMS & & TIL, TYL, ERY, LIN, SPC, OXT \\
\hline 6 & F4-EASTI & $\begin{array}{l}\text { ENR, CEF, AMP, FFN, GEN, } \\
\text { OXT, TMS }\end{array}$ & TIL & TYL, ERY, LIN, SPC \\
\hline 7 & EASTI & FFN, GEN & & $\begin{array}{l}\text { ENR, CEF, AMP, TIL, TYL, } \\
\text { ERY, LIN, SPC, OXT, TMS }\end{array}$ \\
\hline 8 & F4-EASTI & FFN, GEN & & $\begin{array}{l}\text { ENR, CEF, AMP, TIL, TYL, } \\
\text { ERY, LIN, SPC, OXT, TMS }\end{array}$ \\
\hline 9 & F4-EASTI & FFN, GEN & & $\begin{array}{l}\text { ENR, CEF, AMP, TIL, TYL, } \\
\text { ERY, LIN, SPC, OXT, TMS }\end{array}$ \\
\hline 13 & F4-EASTI & FFN, GEN & & $\begin{array}{l}\text { ENR, CEF, AMP, TIL, TYL, } \\
\text { ERY, LIN, SPC, OXT, TMS }\end{array}$ \\
\hline 14 & $S T b-L T-F 4-E A S T I$ & CEF, AMP, FFN, GEN, TMS & SPC & ENR, TIL, TYL, ERY, LIN OXT \\
\hline 15 & $S T b-L T-F 4-E A S T I$ & CEF, AMP, FFN, GEN, TMS & SPC & ENR, TIL, TYL, ERY, LIN OXT \\
\hline 17 & STb-LT-F18-eae-VT1-EASTI-AIDA-I & CEF, GEN & & $\begin{array}{l}\text { ENR, CEF, AMP, TIL, TYL, } \\
\text { ERY, LIN, SPC, OXT, TMS }\end{array}$ \\
\hline 20 & $L T-F 18-E A S T I-A I D A-I$ & GEN & TMS & $\begin{array}{l}\text { ENR, CEF, AMP, TIL, TYL, } \\
\text { ERY, LIN, SPC, FFN, OXT }\end{array}$ \\
\hline 21 & $V T 1-E A S T I$ & GEN & TMS & $\begin{array}{l}\text { ENR, CEF, AMP, TIL, TYL, } \\
\text { ERY, LIN, SPC, FFN, OXT }\end{array}$ \\
\hline 22 & $V T 1-E A S T I$ & GEN & TMS & $\begin{array}{l}\text { ENR, CEF, AMP, TIL, TYL, } \\
\text { ERY, LIN, SPC, FFN, OXT }\end{array}$ \\
\hline 23 & $S T b-L T-F 18-V T 1-E A S T I-A I D A-I$ & CEF, GEN & & $\begin{array}{l}\text { ENR, CEF, AMP, TIL, TYL, } \\
\text { ERY, LIN, SPC, OXT, TMS }\end{array}$ \\
\hline 25 & $S T b-L T-F 18-V T 1-E A S T I-A I D A-I$ & GEN & TMS & $\begin{array}{l}\text { ENR, CEF, AMP, TIL, TYL, } \\
\text { ERY, LIN, SPC, FFN, OXT }\end{array}$ \\
\hline 27 & EASTI & GEN & TMS & $\begin{array}{l}\text { ENR, CEF, AMP, TIL, TYL, } \\
\text { ERY, LIN, SPC, FFN, OXT }\end{array}$ \\
\hline 28 & EASTI & GEN & TMS & $\begin{array}{l}\text { ENR, CEF, AMP, TIL, TYL, } \\
\text { ERY, LIN, SPC, FFN, OXT }\end{array}$ \\
\hline 29 & $V T 1-E A S T I$ & GEN & TMS & $\begin{array}{l}\text { ENR, CEF, AMP, TIL, TYL, } \\
\text { ERY, LIN, SPC, FFN, OXT }\end{array}$ \\
\hline 32 & $S T b-L T-F 4-E S T A I$ & CEF, GEN & & $\begin{array}{l}\text { ENR, AMP, TIL, TYL, ERY, } \\
\text { LIN, SPC, FFN, OXT, TMS }\end{array}$ \\
\hline 33 & F4-EASTI & CEF, GEN & TMS & $\begin{array}{l}\text { ENR, CEF, AMP, TIL, TYL, } \\
\text { ERY, LIN, SPC, OXT }\end{array}$ \\
\hline 34 & EASTI & CEF, GEN, TMS & & $\begin{array}{l}\text { ENR, CEF, AMP, TIL, TYL, } \\
\text { ERY, LIN, SPC, OXT }\end{array}$ \\
\hline 35 & F4-VT1-EASTI & SPC, FFN, GEN & & $\begin{array}{l}\text { ENR, CEF, AMP, TIL, TYL, } \\
\text { ERY, LIN, OXT, TMS }\end{array}$ \\
\hline 37 & EASTI & SPC, FFN, GEN & & $\begin{array}{l}\text { ENR, CEF, AMP, TIL, TYL, } \\
\text { ERY, LIN, OXT, TMS }\end{array}$ \\
\hline 38 & $S T b-L T-F 18-V T 1-E A S T I-A I D A-I$ & $\begin{array}{l}\text { CEF, GEN, ENR, AMP, TIL, } \\
\text { TYL, ERY, LIN, SPC, FFN, } \\
\text { OXT, TMS }\end{array}$ & & \\
\hline 39 & F18-EASTI & CEF, GEN & & $\begin{array}{l}\text { ENR, AMP, TIL, TYL, ERY, } \\
\text { LIN, SPC, FFN, OXT, TMS }\end{array}$ \\
\hline 41 & F18-EASTI-AIDA-I & ENR, CEF, GEN, TMS & & $\begin{array}{l}\text { AMP, TIL, TYL, ERY, LIN, } \\
\text { SPC, FFN, OXT }\end{array}$ \\
\hline 43 & F4-VT1 & CEF, GEN & FFN & $\begin{array}{l}\text { ENR, AMP, TIL, TYL, ERY, } \\
\text { LIN, SPC, OXT, TMS }\end{array}$ \\
\hline 46 & $F 4$ & CEF, SPC, GEN, TMS & & $\begin{array}{l}\text { ENR, AMP, TIL, TYL, ERY, } \\
\text { LIN, FFN, OXT }\end{array}$ \\
\hline 47 & - & CEF & & $\begin{array}{l}\text { ENR, AMP, TIL, TYL, ERY, } \\
\text { LIN, SPC, FFN, OXT, TMS, } \\
\text { GEN }\end{array}$ \\
\hline 52 & - & CEF, SPC, GEN, OXT, TMS & ENR & AMP, TIL, TYL, ERY, LIN, FFN \\
\hline
\end{tabular}

ENR=Enrofloxacin, $C E F=$ Ceftiofur, $A M P=$ Ampicillin, TIM=Tiamuline, TIL=Tilmicosin, ERY=Erythromycin, LIN=Lincomycin, $\mathrm{SPC}=$ Spectinomycin, FFN=Florfenicol, GEN=Gentamicin, TMS=Trimethoprim sulfamethoxazole, TYL=Tylosin, AIDA=Adhesin involved in diffuse adherence

for STx 1, $16.67 \%$ for eae (gene encoding intimine protein), and $2.1 \%$ for $S T x 2$. This fact suggests that pigs with post weaning diarrhea or ED could be reservoirs of pathogenic strains of E. coli [9]. Pigs carrying hemolytic uremic syndrome (HUS)strains could potentially generate an outbreak of that disease not only by possible environmental contamination but also because of participation of pork in the food chain. Fortunately, such strains were not found in this study. 
Bacteriological studies of clinical cases of diarrhea in swine production should be standard practice. However, in developing countries, diarrhea treatment is frequently intuitive or empiric with concomitant multiresistance dissemination [20]. Our results showed important antibiotic resistant profiles among isolates from sick animals such as Okello et al. [12], Luppi et al. [13], and Mathew et al. [11]. GEN and CTF elicited low amounts of resistant strains in accordance with Moredo et al. [1], who found a few antibiotics inactive for ETEC strains from healthy pigs. Dendrograms are useful tools to evaluate distinct drugs or groups of antibiotic resistance in a same pathotype of bacteria.

\section{Conclusion}

In conclusion, we provide information about an important circulation of strains and pathotypes of $E$. coli among pigs with diarrhea. The strains studied showed high resistance profiles, these results could be useful for swine industry.

\section{Authors' Contributions}

Conceived and designs the experiments: FB, FA, and GZ. Perform the experimental procedures: FB, GB, SM, and FA. Analyzed the data: FB, FA, and MC. Wrote the paper: FB, FA, and GZ. All authors read and approved the final manuscript

\section{Acknowledgments}

This work was financially supported by PNSA-1115057 Instituto Nacional de Tecnologia Agropecuaria (INTA).

\section{Competing Interests}

The authors declare that they have no competing interests.

\section{References}

1. Moredo, F., Piñeyro, P., Márquez, G. and Sanz, M. (2015) Enterotoxigenic Escherichia coli subclinical infection in pigs: Bacteriological and genotypic characterization and antimicrobial resistance profiles. Foodborne Pathog. Dis., 12(8): 704-711

2. Fairbrother, J., Nadeau, E. and Gyles, C. (2005) Escherichia coli in post weaning diarrhoea in pigs: An update on bacterial types, pathogenesis, and prevention strategies. Anil $\mathrm{H}$. Res Rev., 6: 17-39.

3. Nagy, B. and Fekete, P. (2005) Enterotoxigenic Escherichia coli in veterinary medicine. Int. J. Med. Microbiol., 295: 443-454.

4. Gyles, C.L. and Fairbrother, J.M. (2010) Escherichia coli. In: Gyles, C.L., Prescott, J.F., Songer, J.G., Thoen, C.O., editors. Pathogenesis of Bacterial Infections in Animals. Wiley-Blackwell, Ames, Iowa. p267-308.

5. Ozaki, C.Y., Silveira, C.R.F., Andrade, F.B., Nepomuceno, R., Silva, A., Munhoz, D.D., Yamamoto, B.B., Luz, D., Abreu, P.A., Horton, D.S.P., Elias, W.P. and Ramos, O.H.P. (2015) Single chain variable fragments produced in Escherichia coli against heat-labile and heat-stable toxins from enter toxigenic E. coli. PLoS ONE, 10(7): e0131484.

6. Rodríguez, A.G. (2002) Main characteristics and diagnosis of pathogenic groups of Escherichia coli. Salud Pública
Méx., 44(5): 464-475.

7. Fekete, P., Schneider, G., Olasz, F., Blum-Oehler, G., Hacker, J. and Nagy, B. (2003) Detection of plasmid encoded pathogenicity island in F18+ enter toxigenic and verotoxigenic Escherichia coli in weaned piglets. Int. J. Med. Microbiol., 293: 287-298.

8. Mainil, J., Jacquemin, E., Pohl, P., Kaeckenbeeck, A. and Benz, I. (2002) DNA sequences coding for the F18 fimbriae and AIDA adhesion are localized on the same plasmid in Escherichia coli isolates from piglets. Vet. Microbiol., 86: 303-311.

9. Colello, R., Etcheverría, A., Di Conza, J., Gutkind, G. and Padola, N. (2015) Antibiotic resistance and integrons in Shiga toxin-producing Escherichia coli (STEC). Braz. J. Microbiol., 46(1): 1-5.

10. Fairbrother, J. and Gyles, C. (2012) Colibacillosis. In: Zimmerman, J., Karriker, L., Ramirez, A., Schwartz, K. and Stevenson, G., editors. Diseases of Swine. $10^{\text {th }}$ ed. WileyBlackwell, Ames, Iowa. p723-749.

11. Mathew, A.G., Cissell, R. and Liamthong, S. (2007) Antibiotic resistance in bacteria associated with food animals: A United States perspective of livestock production. Foodborne Pathog. Dis., 4: 115-133.

12. Okello, E., Moonens, K., Erume, J. and de Greve, H. (2015) Enterotoxigenic Escherichia coli strains are highly prevalent in Ugandan piggeries but disease outbreaks are masked by antibiotic prophylaxis. Trop. Anim. Health Prod., 47: $117-122$

13. Luppi, A., Bonilauri, P., Dottori, M., Gherpelli, Y., Biasi, G., Merialdi, G., Maioli, G. and Martelli, P. (2012) Antimicrobial resistance of F4+ Escherichia coli isolated from Swine in Italy. Transbound. Emerg. Dis., 62: 67-71.

14. Moredo, F., Cappuccio, J., Insarralde, L., Perfumo, C., Quiroga, M. and Leotta, G. (2012) Genotypic characterization of toxigenic Escherichia coli isolated from pigs with postweaning diarrea (PWD) and edema disease (ED). Rev. Arg. Microbiol., 44: 85-88.

15. Alustiza, F., Picco, N., Bellingeri, R., Terzolo, H. and Vivas, A. (2012) Frequency of virulence genes of Escherichia coli among new born piglets from an intensive pig farm in Argentina. Rev. Argent. Microbiol., 44: 250-254.

16. Fekete, P., Gerardin, J., Jacquemin, E., Mainil, J. and Nagy, B. (2002) Replicon typing of F18 fimbriae encoding plasmids of enter toxigenic and verotoxigenic Escherichia coli strains from porcine post weaning diarrhoea and edema disease. Vet. Microbiol., 85: 275-284.

17. Vu-Khac, H., Holoda, E., Pilipcinec, E., Blanco, M., Blanco, J., Dahbi, G., Mora, A., Lopez, C., Gonzalez, E. and Blanco, J. (2007) Serotypes, virulence genes, intimin types and PFGE profiles of Escherichia coli isolated from piglets with diarrhoea in Slovakia. Vet. J., 174: 176-187.

18. Wieler, L., Ilieff, A., Herbst, W., Bauer, C., Vieler, E., Bauerfeind, R., Failing, K., Kloès, H., Wengert, D., Baljer, G. and Zahner, H. (2001) Prevalence of enter pathogens in suckling and weaned piglets with diarrhoea in Southern Germany. J. Vet. Med., 48: 151-159.

19. NCCLS. (2014) NCCLS Stands for National Committee for Clinical Laboratory Standards 2014. Actualized Manual. Vol. 35. p3.

20. Schwartz, S., Silley, P., Simjee, S., Woodford, N., van Duijkeren, E., Johnson, A.P. and Gaastra, W. (2010) Assessing the antimicrobial susceptibility of bacteria obtained from animals. Vet. Microbiol., 141(1-2): 1-4.

21. Di Rienzo, J.A., Casanoves, F., Balzarini, M.G., Gonzalez, L., Tablada, M. and Robledo, C.W. (2015) InfoStat Versión 2011 Grupo InfoStat, FCA, Universidad Nacional de Córdoba, Argentina. Available from: http:// www.infostat.com.ar.

22. Parma, A., Sanz, M., Viñas, M., Cicuta, M., Blanco, J.E., Boehringer, S., Vena, M., Roibon, W., Benitez, M., Blanco, J. and Blanco, M. (2000) Toxigenic Escherichia coli isolated from pigs in Argentina. Vet. Microbiol., 72: 269-276. 
23. Li, Y., Qiu, X., Li, H. and Zhang, Q. (2007) Adhesive patterns of Escherichia coli $\mathrm{F} 4$ in piglets of three breeds. $J$. Genet. Genomics, 34: 591-599.

24. Choi, C., Kwon, D. and Chae, C. (2001) Prevalence of the enter aggregative Escherichia coli heat-stable enterotoxin 1 gene and its relationship with fimbrial and enterotoxin genes in E. coli isolated from diarrheic piglets. J. Vet. Diagn. Invest., 3: 26-29.
25. Cheng, D., Zhu, S., Cheng, X., Gao, X., Ding, W. and Sun, H. (2010) Rapid diagnosis of ETEC and HPI-harboring Escherichia coli infection in new born piglets with diarrhoea. Afr. J. Microbiol. Res., 4: 575-580.

26. Rivas, M., Miliwebsky, E., Chinen, I., Deza, N. and Leotta, G. (2006). The epidemiology of hemolytic uremic syndrome in Argentina. Diagnosis of the etiologic agent, reservoirs and routes of transmission. Med. B. Aires, 66(3): 27-32.

$* * * * * * * *$ 